\title{
Mamardashvili, an Observer of the Totality.
}

\section{About "Symbol and Consciousness", and the cross between: East and West, infinity and finiteness}

\author{
Vasil Penchev, vasildinev@gmail.com \\ Bulgarian Academy of Sciences: Institute of Philosophy and Sociology
}

\begin{abstract}
The paper discusses a few tensions "crucifying" the works and even personality of the great Georgian philosopher Merab Mamardashivili: East and West; human being and thought, symbol and consciousness, infinity and finiteness, similarity and differences. The observer can be involved as the correlative counterpart of the totality: An observer opposed to the totality externalizes an internal part outside. Thus the phenomena of an observer and the totality turn out to converge to each other or to be one and the same. In other words, the phenomenon of an observer includes the singularity of the solipsistic Self, which (or "who") is the same as that of the totality. Furthermore, observation can be thought as that primary and initial action underlain by the phenomenon of an observer. That action of observation consists in the externalization of the solipsistic Self outside as some external reality. It is both a zero action and the singularity of the phenomenon of action. The main conclusions are: Mamardashvili's philosophy can be thought both as the suffering effort to be a human being again and again as well as the philosophical reflection on the genesis of thought from itself by the same effort. Thus it can be recognized as a powerful tension between signs ana symbol, between conscious structures and consciousness, between the syncretism of the East and the discursiveness of the West crucifying spiritually Georgia.
\end{abstract}

Key words: Mamardashvili, "Symbol and Consciousness", the totality, observer, infinity, finiteness 
The objectivity is the works and personality, and even life of the great philosopher Merab Mamardashvili to be interpreted as a sufferance and crucifixion between:
a) East and West
b) Human being and thought
c) Symbol and consciousness
d) Infinity and finiteness
e) Similarity and differences

"East and West" is a crucifixion between the wholeness of symbol and the necessity for it to be expressed in a partial way to be articulated and realized by consciousness. That crucifixion is thought at all as well as any thought, but reflection, the philosophical thinking is just that sufferance and suffering on the cross "each and any minute", the effort of human being to be a human being.

"Similarities and Differences" is the similarity of the oneness before crucifixion both "and" and "versus" the differences of plurality after crucifixion. There is anyway some mystery or sacrament after all because the oneness resurrects unifying those "Similarities and Differences" as a common and joint whole. Even more, that crucifixion is the true or even single way for the oneness of thought to be: Thought is only that philosophical suffering or human sufferance.

This way of interpretation is a philosophical effort, suffering, and thinking. It suggests the spirit of Mamardashvili to be put to death again and again to be able to resurrect.

\section{How?}

Representing it a simple scheme as above and thus as an infinite bad repetition in the way as Mamardashvili figured and described Inferno. He used to utilize metaphors and similes in a visible effort and crucifixion to express and think the inexpressible to be in it, in philosophy, in human being: in himself in final analysis. One can involve a scientific concept (that of fractal) as a metaphor for thought rather than a notion.

\section{Then:}

The fractal of that interpretation is a suffering and thus disturbing crystallization. Its germ will be sought after "Symbol and Consciousness" (with Alexander Piatigorsky as Mamardashvili's coauthor) and devoted to the return of the Western philosophy into its symbol of thought. Crucifixion and return, crucifixion and resurrection are the initial sacrament of philosophy as if represented by both coauthors and close friends. 
Gori, Georgia is the birthplace of Mamardashvili ... and of Stalin.

Georgia is situated just on the crossroads of Asia and Europe therefore symbolizing even by its historical destiny the crucifixion and unification between East and West:

The Cross, Crucifixion is the Georgian flag: Its name is "Five Cross Flag".

However, Mamardashvili was always against any national exclusivity: Mamardashvili categorically opposed any nationalism either Russian or Georgian, or any other one as well as the idea of national exclusivity in general.

Nevertheless, Mamardashvili touched the essence both of thought and of philosophical reflection being just a Georgian: He managed to reveal that deep level in the Georgian or Russian soul, which is universal for philosophy, thought and mankind, and in relation to which, to the task of thought, any nationalism or pretense for national exclusivity is only a huge obstacle.

The "Five Cross Flag" can be considered as that metaphor of fractal: Its sense is consciousness on the cross.

The consciousness is crucified by two opposed trends: It should manage to keep the symbol without any simple repetition in any "bad infinity", which puts it to death. It should manage to keep the symbol in creativity without chaos to tear it to pieces. Even more, consciousness really exists only on that Cross, in its Centre, in the oneness of both trends tearing it: It is a constant effort again and again to be consciousness.

Five citations from "Symbol and Consciousness" are chosen:

2. The understanding of symbol as not-sign: symbol is the sign of nothing: "понимания символа как не-знака”; “символ в собственном смысле есть знак ничего” (Mamardashvili 1982: 94; 96).

3. Less and less symbols: from the situation of understanding to the situation of knowledge: “в мировосприятии современного культурного человека символов становится все меньше и меньше внутри наших знаковых систем”; “символы переходят ('переводят нас') из ситуации понимания в ситуацию знания” (Mamardashvili 1982: 102).

4. Consciousness hides itself "in itself”: “сознание как таковое - с установкой на полное, максимальное понимание - от нас уходит (или, как сказали бы древние индийцы, 'уходит в себя')" (Mamardashvili 1982: 210).

5. Consciousness and culture are actively progressing incompatible to each other: "сознание 
и культура выявляют в отношении друг друга такое свойство, как активная прогрессирующая несовместимость” (Mamardashvili 1982: 187).

1. The objectivity of the book is the interpretation of symbol in a sense of consciousness: “Цель этой книги - истолкование символа в смысле сознания” (Mamardashvili 1982: 85).

Three preliminary notes concerning three crosses:

a) The "cross" of 'finiteness - infinity' and 'symbol - consciousness'

b) The "cross" of 'externality - internality' and 'symbol - consciousness'

c) The "cross" of 'differences - similarity' and 'symbol - consciousness'

These three "crosses" are one and the same in a sense unifying and unified by "symbol consciousness', which will be explicated a little below:

The first one, 'finiteness - infinity' and 'symbol - consciousness': Both symbol and consciousness are rather on the side of infinity, but both can explicate themselves into finiteness correspondingly as signs or "structures of consciousness". Though the following property of them is too paradoxical, both are equivalent to their finite representations as signs or structures being random. Thus both symbol and consciousness guarantee choice, freedom, freewill and responsibility which are necessary for that equivalence.

The second one, 'externality - internality' and 'symbol - consciousness': Symbol is rather external in relation to an observer while that observer is always internal in relation to consciousness. Thus symbol and consciousness represent the oneness of the totality split by the availability of any observer necessary internal to it (for the totality should be 'total' indeed). Therefore symbol represents the externality of the totality in relation to any observer as the true totality contents its externality in itself being just 'total'.

A visualization of both oppositions 'differences - similarity' and 'symbol - consciousness' would be the following:

Both symbol and consciousness unlike correspondingly signs or structures are on the side of similarity, even of the oneness. That similarity is decomposed into identities and differences representable by signs (outside) or structures of consciousness (inside). The signs, to which the observer is external, can be manipulated in mental operations. The structures of consciousness, to which the observer is internal, allow of the being to be ordered.

How can these three "crosses" be one and the same? Of course, all three are only signs referring to some hidden symbol, which unifies them remaining hidden and inexplicable in principle, and thus 
allowing of new and new signs again and again. The philosophical reflection is concentrated on that suffering birth of the signs rather than on their meaning or on the symbol, which they cannot ever represent absolutely.

Thus Mamardashvili philosophically thought of Georgia constantly crucified in the initialization of the West from the East.

Symbol should understand as not-sign: symbol is the sign of nothing. Symbol is not a sign of anything: If any sign refers to other signs, which precede or follow it, symbol does not refer to anything both as it is the beginning of all signs, which it generates, and as there is a leap from it to any ensemble of signs generated by it. Symbol is just the sign of nothing as it refers only to the totality, however to the "other side" of it, outside, its externality, from which it is nothing.

There are less and less symbols in the "West": It moves from the situation of understanding to the situation of knowledge. The "West" as on west as on east lives in the established structures of signs, which one should know to be socialized by a whole series of sign structures such as language, society, science, technics, and even religion. However, one does not need to understand them to utilize them. They require only knowledge. New sign structures therefore directly addressing symbols appear extremely rare while those enumerated above are developed only, and their symbolic origin is redundant and forgotten.

There is an initial motion of philosophical thought directed from symbol to consciousness "outside": Indeed the former two citations refer to "symbol", and the latter two ones to consciousness. This suggests the consciousness to be entered in a way hidden for any sign or conscious structures, namely outside, from the side of symbol:

One can offer the following visualization of how consciousness hides itself "in itself" "by itself": That way "outside" can display why and how consciousness can hide and hides itself "in itself" being referring to symbol: It hides itself "in itself" in relation to any sign or conscious structures as it is only their or any wholeness. On the contrary, all sign or conscious structures constitute themselves about their expansion only which is able to guarantee their openness. Thus they are always partial.

A reference to Heidegger could be the following: Let consciousness be entered "outside", from the "side" of symbol and hidden for any observer if that one identifies oneself by any knowledge of any structures. If that is the case, consciousness is only openness, unhiddenness, $\dot{\alpha} \lambda \hat{\eta} \theta \varepsilon 1 \alpha$, the way, in which Heidegger introduces truth as entering the totality. Here, "consciousness" is only a sign of the totality. 
The fundamental concept of phenomenology, that of phenomenon can be interpreted as an original and initial invariance in relation to the fundamental opposition of classical philosophy, that of subject and object. Consequently phenomenon can be thought as an initial structure or "eidos" of any entity, which is as single as plural. In particular, its plurality requires at least doubling, just which classical philosophy designates and studies as that opposition of subject and object.

Furthermore that concept of phenomenon correlates with that of the totality generating and/ or generated by a counterpart in terms of the totality. That "plural singularity" of the phenomenon can be directly deduced from the definitively necessary properties of the totality: any externality of the totality should be within it just being total. Thus the totality generates infinity in itself by itself and can be thought as equivalent to infinity in a restricted sense.

The observer can be involved as the correlative counterpart of the totality: An observer opposed to the totality externalizes an internal part outside. Thus the phenomena of an observer and the totality turn out to converge to each other or to be one and the same. In other words, the phenomenon of an observer includes as the necessity singularity of the solipsistic Self, which (or "who") is the same as that of the totality.

Furthermore, observation can be thought as that primary and initial action underlain by the phenomenon of an observer as above. That action of observation consists in the externalization of the solipsistic Self outside as some external reality. It is both a zero action and the singularity of the phenomenon of action.

As a zero action, it serves as a reference frame, in which any other action can be situated and thus its phenomenon can be yielded. The essence of that zero action consists in the totality to be ordered in a "zero" way so that to be the same or to remain the same after being ordered as reality. That condition constitutes observation as that, to which the totality is invariant in the two hypostases: (1) a primary and initial "chaos" unorderable in principle and (2) the reality, which is already somehow well-ordered within it and by itself.

As the singularity of the phenomenon of action, the "action" of observation is the common ground of all actions and therefore making them both possible and juxtaposable. Thus it can be "bracketed" so that as if only reality and real actions take place and so grounding the natural attitude to the world, commonly shared by people.

Furthermore, observation as if generating reality should be discussed in terms of ordering. The phenomenon of ordering is choice: Ordering represents a primary choice between the ordered and 
(the) unordered i.e. between at least two alternatives, among which only one should be chosen as ordering rejecting all the rest. Consequently ordering is equivalently representable as a series of choices or even as a single choice in a philosophical sense: the choice to be chosen the choice itself and therefore choosing ordering and reality. However reality hides that choice, which generates it. The mechanism for the choice underlying reality to be hidden can be found in observation as follows:

The observation itself is invariant to the choice. Observation is just the zero action: that action, which is "not" yet an action, but a reference frame or benchmark, to which any other, "real" action can be constituted as adequate to reality somehow already existing "in advance". Thus observation needs only some pure existence to remain from the choice after it is invariant to that choice and does not need it properly but only the abstract, "pure" existence (of it or at all). After the choice turns out to be hidden, only the result of the choice, i.e. reality is only what can be endowed with that unconditional existence.

Therefore and as a conclusion, the phenomenon of observation as a "zero action" is what can constitute reality as somehow already ordered ostensibly by itself and thus ground the natural attitude to the world as properly natural hiding all process of the phenomenological genesis of it.

Furthermore, consciousness and culture are actively progressing incompatible to each other: After consciousness has been understood as pure openness from the side of symbol, and culture as an established sign structure, by which the observer orders the world, their incompatibility is obvious. Even more, the development of culture being the extension and intensification of a sign structure wanders from the symbol. They frustrate each other more and more: signs vs. symbol just as culture vs. consciousness... Nevertheless consciousness is just the sign structure of culture. It hides itself by itself again...

One can interpret symbol in a sense of consciousness: This is the unifying center of the book "Symbol and Consciousness". However this is a tautology: The four terms: interpretation, symbol, sense, and consciousness mean one and the same: The book hides itself in itself by itself just where it reveals its objectivity and thus essence. Symbol and consciousness is only a doubling, two terms about one and the same, though...

Symbol and consciousness can be seen as pure doubling, and that doubling and its further redoubling in sings or structures generate the world. If one starts from the signs and structures, symbol and consciousness is not anything different from them. They are not more than signs and structure, but seen once again, in their wholeness. Indeed an ancient oriental wisdom says: "A man sees 
mountains and a sea, the pupil sees something different, but the wise man sees again mountains and a sea”.

A note about time and language is necessary: Time can be considered as the condition of language and thus for extending a sign or conscious structure: Time can be thought as an initial and primary language of the being, in which the signifier and signified coincide with each other and thus with the sign in principle generating the "things themselves" as "phenomena". However, Mamardashvili and Piatigorsky's symbol should be thought beyond or before even that "phenomenon", i.e. before or beyond the time, namely by the sign of "death" as transcending the time.

Another note about time and the totality follows: Both "Symbol and Consciousness" should be realized in terms of the totality: Time expresses the totality entirely. Nevertheless an inexplicable remainder appears always. Derrida coined the term of "mute difference" written as "differance" to explicate it somehow anyway. However both time and the totality and thus symbol and consciousness are neither subjective nor objective though they can be interpreted in both ways .

These four motifs enumerated above (2-5) can be seen as originating from a central motif (1) originating from nowhere and therefore being a simple tautology or doubling and redoubling... In turn these four motifs can be followed in other papers of Mamardashvili extending a fractal structure of (")Symbol and Consciousness(") as what the flag of Georgia is: Five Cross Flag five times in turn:

The key for decoding is the following: Any fractal structure contents the key to be decoded in itself and by itself. If any other language as some encoding is conventional and thus requires an external vocabulary as a key to be decoded, the fractal structure is also its key and thus it is natural, being, and existing unlike any other language, which is artificial referencing to some other knowledge for interpretation.

A continuation of the same fractal structure can be followed in citations from other papers or talks of Mamardashvili:

2.2. God (in culture) is a symbol of some force compensating the deficiency in our efforts: "B культуре (а не в религии) Бог - это символ некоторой силы, которая действует в мире вопреки нашей глупости, непониманию, неумению или нежеланию понимать некоторые состояния, к которым мы не могли прийти своими собственными силами, но которые тем не менее являются фактами" (Mamardashvili 1989a: 34).

2.3. Modified objects (e.g. irrational expressions) are signs (symbols) of the difference 
between being and consciousness: “превращенные объекты (иррациональные выражения, «желтые логарифмы») как знаки, «свидетельства» неустранимого различия между бытием и сознанием, как символы того, что при всей слитости в некотором общем континууме бытие и сознание не могут быть отождествлены" (Mamardashvili 1970: 281).

2.4. No subject for any symbol, e.g. for that of "the supreme good" in particular: "Я уже ввел понятие "высшего блага", точнее, символ - не понятие, поскольку оно, как сказал бы Кант, не имеет созерцания, на котором оно могло бы быть разрешено. То есть под это понятие нельзя подставить никакой конкретный предмет" (Mamardashvili 1988d: 235).

$2.4+$ The human being is always "self-making", its state consists of births again and again:

“Таким образом, человек - это, очевидно, единственное существо в мире, которое (как человеческое существо, в том смысле, что оно не порождается Природой, которую мы можем изучать объективированно - в какой-то картине, отвлеченной от себя) находится в состоянии посеянного зановорождения,...” (Mamardashvili 1988d: 237).

2.4++ The human being is being born all over again and again by means of symbols: both in religion and in philosophy: “и это зановорождение случается лишь в той мере, в какой человеку удается собственными усилиями поместить себя в свою мысль, в свои стремления, в некоторое сильное магнитное поле, сопряженное предельными символами. Эти символы на поверхности выступают, с одной стороны, в религии (точнее, в мировых религиях, то есть не этнических, не народных), а с другой стороны, в философии" (Mamardashvili 1988d: 237).

2.5. Symbol is what we are ourselves, and understand always only incompletely. The philosophical works are that incompleteness expressed in infinite expression: “Символ (не знак!) всегда есть то, что мы не до конца понимаем, но что есть мы сами как понимающие, как существующие. И наши философские произведения, и их чтение есть форма существования этого до конца непонимаемого, его бесконечной длительности и родственной самосогласованности" (Mamardashvili 1988c: 10).

3.2. There exists philosophy always, the doctrines are optional: “Доктрин может не быть, а философия существует" (Mamardashvili 1979: 125). 
3.3. Philosophy is a second "birth" in thought after a symbolic death: “определения философии как формы, позволяющей нам испытать то, что без нее мы не могли бы испытать. То есть рождаться второй раз, согласно древнему символу «второго рождения»" (Mamardashvili 1988b: 59).

$3.3+$ Philosophy is an initial germ, which only develops by concepts in an infinite cultural form: “И в этом смысле философия является как бы бесконечной культурной формой. То есть она содержит в себе некоторые уже заданные ее целостностью моменты или зерна, которые могут когда-то и кем-то выявляться, развиваться с помощью понятий, но сами возможности этого развития будут содержаться уже в самом факте конституирования философии" (Mamardashvili 1988b: 55).

3.4. One creates oneself as a human being again and again by individual efforts: "Человек создается. Непрерывно, снова и снова создается. Создается в истории, с участием его самого, его индивидуальных усилий. И вот эта его непрерывная создаваемость и задана для него в зеркальном отражении самого себя символом «образ и подобие Божье». То есть Человек есть такое существо, возникновение которого непрерывно возобновляется. С каждым индивидуумом и в каждом индивидууме" (Mamardashvili 1988c: 10).

3.5. "The symbolic element of rationality" is the title of the chapter 5 in "The classical and non-classical ideal of rationality”: “5. СИМВОЛИЧЕСКИЙ ЭЛЕМЕНТ РАЦИОНАЛЬНОСТИ” (Mamardashvili 1984).

4.2. Consciousness should define only self-referential as producing itself as more consciousness: "В грамотной философии сознание не определяется, т.е. сознание определяется так: сознание есть то, что есть возможность большего сознания; свобода есть то, что есть возможность большей свободы, т.е. свобода производит только свободу" (Mamardashvili 1988d: 239).

4.2+ As well as freedom: “В том числе и такие символы, как «человек», «смерть», «смысл жизни», «свобода» и т.д. Это ведь вещи, производящие сами себя. Даже сознание, как и мысль, можно определить как возможность болышего сознания. Или, например, свобода. Для чего 
нужна свобода и что она? Свобода ничего не производит, да и определит ее как предмет нельзя. Свобода производит только свободу” (Mamardashvili 1988c: 11).

4.3. Well, figure a scientific researcher in the Academy of Sciences. Can (s)he have that universal consciousness?: “А теперь, представьте научного сотрудника Академии наук. Может ли он иметь то сознание, которое я вам описывал как универсальное?” (Mamardashvili 1979: 130).

4.4. The consciousness of "cogito" coincides with its contents, doubles it: “когитальное сознание есть ухватывание сознанием в любом осознаваемом содержании самого факта, что "я его сознаю", чем и исчерпывается это содержание как сознательное явление" (Mamardashvili 1984: 15). “Иначе говоря, в данном случае концептуальное сознание происшествия явления совпадает с его содержанием и последнее не может быть отделено от первого" (Mamardashvili 1984: 16).

4.5. Speaking of being is speaking of consciousness in a special sense: "когда говорится о бытии, то в особом смысле говорится и о сознании” (Mamardashvili 1996: 49).

5.2. Culture is infinite: The symbol of death means the transformation in thought being due to our efforts: "Культура - бесконечна. Однако у такого рода бесконечности есть, естественно, и элемент дурной бесконечности. И, более того, выпадение из нее, обращение к мысли обязательно связано с появлением символа смерти, потому что к мысли мы можем прийти, только изменившись, перестав быть прежними. Следовательно, онтологическое устройство бытия воспроизводит себя лишь с включением нашего усилия, когда, во-первых, мы становимся другими, чем были до этого, и, во-вторых, приходим к этому нашим непрерывным продолжением самих себя" (Mamardashvili 1989b: 77).

5.3. Consciousness is singulare tantum, a single "many-much", or a multiple oneness: "Het множественного сознания. Как говорили мистики - и я с удовольствием повторяю эту формулу - сознание представляет собой singulare tantum, то есть ножественное-единственное. Множественную единичность, скажем так” (Mamardashvili 1996: 71).

5.4. Human consciousness and its "annex" called civilization: “человеческое сознание и 
связанная с ним «пристройка», называемая цивилизацией” (Mamardashvili 1988a: 58).

5.5. Struggle with consciousness: It becomes knowledge and ... vanishes: "Борьба с сознанием означает, что стремлением человека сознание перестает быть чем-то спонтанным, относящимся к природе, автоматически функционирующим. Сознание становится познанием и на это время (слово "время" здесь не имеет физического смысла) перестает быть сознанием и как бы становится метасознанием" (Mamardashvili 1971: 346).

Thus "Symbol and Consciousness" can be seen as an infinitely extending structure in Mamardashvili's works and further, in the contemporary philosophy and culture at all.

Two main conclusions:

Mamardashvili's philosophy can be thought both as the suffering effort to be a human being again and again as well as the philosophical reflection on the genesis of thought from itself by the same effort.

Thus it can be recognized as a powerful tension between signs an symbol, between conscious structures and consciousness, between the syncretism of the East and the discursiveness of the West crucifying spiritually Georgia. 


\section{References:}

Mamardashvili, M. (1970) Modified forms: On the necessity of irrational expressions [Prevrashchennye formy. O neobhodimosti irracional'nyh vyrazhenii]. In: Mamardashvili, M. Kak ia ponimaiu filosofiu (red. Iu. P. Senokosov). Moscow: „Progress“, $2^{\text {nd }}$ ed., 1992, pp. 269-282.

Also available at http://philosophy.ru/library/mmk/forms.html .

Mamardashvili, M. (1971) Three talks (with Piatigorsky) on the metatheory of consciousness [Tri besedy o metateorii soznaniia (s Piatigorskim)]. Trudy po znakovym sistemam, 5. Tartu: TGU, 1971, pp. 345-376.

Also available at http://gtmarket.ru/laboratory/basis/3278/3281 .

Mamardashvili, M. (1979) Contemporary European philosophy (20 century) [Sovremennaia evropeiskaia filosofiia (XX vek)]. Logos (Moscow) 1991(2), 109 -130.

Also available at http://philosophy.ru/library/mmk/phil_xx.html .

Mamardashvili, M., Piatigorskii, A. (1982). Symbol and consciousness (metaphysical reflections on consciousness, symbolism, and language) [Simvol $i$ soznanie (metafizicheskie rassuzhdeniia o soznanii, simvolike I iazyke ], 2 ${ }^{\text {nd }}$ edition. Moscow: Shkola “Iazyki russkoi kultury”, 1997, 224 p.

Also available at http://philosophy.ru/library/mmk/simvol.html .

Mamardashvili, M. (1984) The classical and non-classical ideal of rationality [Klasicheskii $i$ neklasisicheskii idealy ratsional'nosti]. Sankt Petersburg: «Azbuka - Attikus», 2010, 283 p.

Also available at http://philosophy.ru/library/mmk/knir/mam_rat.html .

Mamardashvili, M. (1988a) Consciousness and civilization [Soznanie i civilizaciia]. Priroda (Moscow) 1988(11), 57-65; Also: Letter Internatlonale (Paris) 1990 (25), 57-60.

Also available at http://psylib.org.ua/books/ mamar02.htm .

Mamardashvili, M. (1988b) Phenomenology is an accompanying entity of any philosophy [Fenomenologiia - sopustvuiuscchii moment vsiakoi filosofii]. Voprosy filosofii (Moscow), 1988 (12), $55-59$.

Also available at http://philosophy.ru/library/mmk/phenom.html .

Mamardashvili, M. (1988c) Philosophy is consciousness aloud [Filosofiia - eto soznanie vsluh]. Iunost’ (Moscow), 1988(12), 9-13.

Also available at http://philosophy.ru/library/mmk/vsluh.html . 
Mamardashvili, M. (1988d) The problem of Human Being in Philosophy [Problema cheloveka v filosofii]. Silentium (Sankt Petersburg), 1991(1), 231-242.

Also available at http://www.spbric.org/PDF/sill1.pdf, http://philosophy.ru/library/mmk/homo.html. Mamardashvili, M. (1989a) Being a philosopher is destiny [Byt' filosofom - eto syd'ba]. Filosofskaia i cotsiologicheskaia mysl' (Kiev). 1989(2), 29-36.

Also available at http://philosophy.ru/library/mmk/fatum.html .

Mamardashvili, M. (1989b) Thought in Culture [Mysl'v culture]. Filosofskie nauki (Moskow), 1989(11), $75-81$.

Also available at http://philosophy.ru/library/mmk/kultura.html .

Mamardashvili, M. (1996) Introduction in philosophy [Vvedenie v filosofiiu]. Mamardashvili, M. Filosofskie chteniia. Sankt Petersburg: "Azbuka - klassica”, 2002, pp. 4-85.

Also available at http://psylib.org.ua/books/mamar02/index.htm . 